\title{
Familial Occurrence of Letterer-Siwe Disease
}

\author{
EMIL FREUNDLICH, SARAH AMIT, YOHAN MONTAG, HARRY SUPRUN, \\ and SARAH NEVO
}

From the Departments of Pediatrics and Pathology, Nahariya Government Hospital, Nahariya, and Haifa University and Human Genetics Clinic, Rambam Hospital, Haifa, Israel

Freundlich, E., Amit, S., Montag, Y., Suprun, H., and Nevo, S. (1972). Archives of Disease in Childhood, 47, 122. Familial occurrence of Letterer-Siwe disease. Letterer-Siwe disease occurred in 4 infant sibs from two consanguineous families. An identical clinical course and pathological picture was observed in all 4 infants.

The occurrence of families with multiple cases supports the hypothesis of genetic causation in Letterer-Siwe disease. The family patterns are in accord with an autosomal recessive inheritance.

Letterer-Siwe disease is part of the histiocytosis$\mathrm{X}$ syndrome. It is characterized by widespread involvement of the viscera, soft tissues, and skin, but only occasionally of bones. A fulminating course is typical and the outcome is usually fatal.

The occurrence of Letterer-Siwe disease in sibs and twins suggests a possible genetic role in the aetiology. We report here 2 additional families, each with more than one affected sib; in each family the parents were consanguineous.

\section{Case Reports}

The $\mathrm{K}$ family (Fig. 1).

Sib 1. V1-1, a male, the firstborn child to a healthy young couple, developed normally until the age of 9 weeks, when he was referred to hospital on account of pallor, generalized lymphadenopathy, and hepatosplenomegaly. The only relevant findings were anaemia, $\mathrm{Hb} 6 \mathrm{~g} / 100 \mathrm{ml}$, and a platelet count of $14,000 / \mathrm{mm}^{3}$. $X$-ray examination of the skeleton and lungs was normal. Biopsy of an axillary lymph node showed a typical picture of histiocytosis, with proliferation of fairly welldifferentiated histiocytes. The infant developed severe bleeding from the nose and rectum, with subcutaneous haemorrhage in various tissues and organs. Microscopically, bone marrow, liver, lymph node, and lung showed typical involvement in the form of aggregates or diffuse infiltration by histiocytic-type cells. These were arrayed in the interlobular septa of the lungs, portal spaces of the liver, and the renal interstitium.

Sib 2. VI-3 was a female born two years after the first sib. The infant had a closed sacral myelocele with mild paresis of both legs. No other abnormal findings were recorded at birth. She developed well until the

Received 18 June 1971.

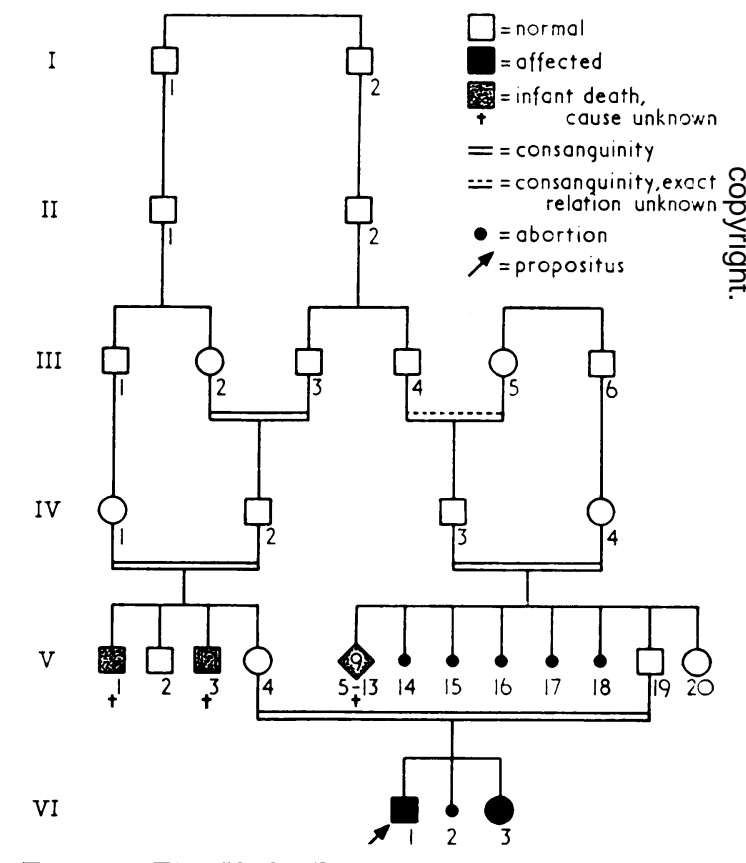

FIG. 1.-The $K$ family. Note pattern of recurrent consanguineous marriages.

age of 11 weeks when referred to hospital for hepatosplenomegaly with a generalized lymphadenopathy and a purpuric rash over both legs. The infant died suddenly on the next day. At necropsy the liver, spleen, lymph nodes, kidneys, and lungs were infiltrated with histiocytic cells, causing similar structural changes to those observed in sib 1 . 


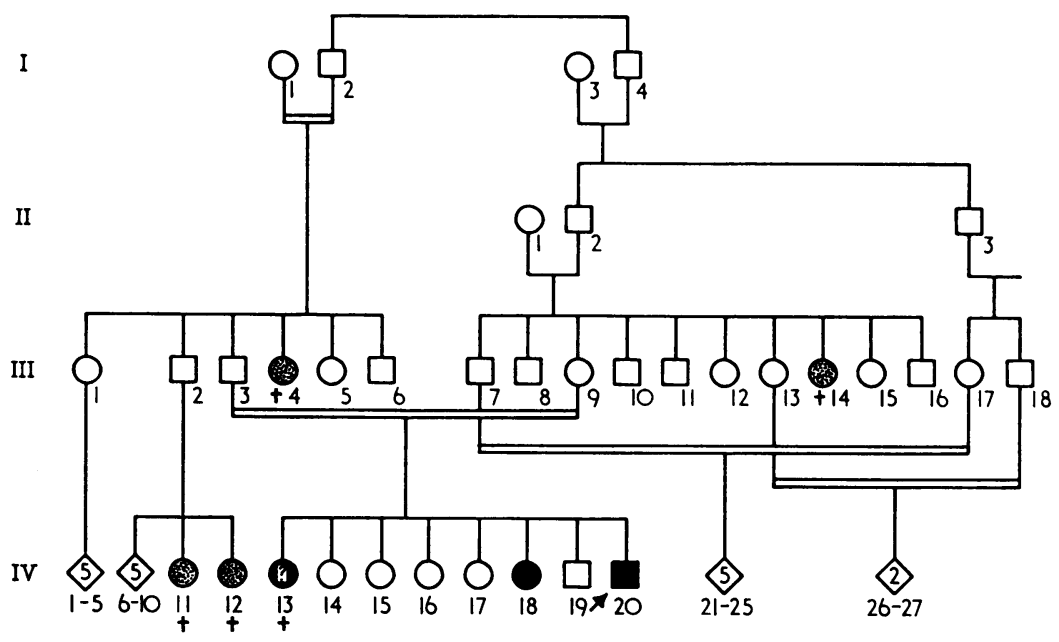

FIG. 2.-The $S$ family.

The $\mathbf{S}$ family (Fig. 2)

Sib 1. IV-18 was a female, the 6th child born to a healthy couple. She was referred at the age of 10 weeks for fever, nasal bleeding, vomiting, and jaundice, when a generalized lymphadenopathy and splenomegaly were found and later a purpuric rash developed. Laboratory findings included $\mathrm{Hb} 5.9 \mathrm{~g} / 100 \mathrm{ml}$, and a platelet count of $80,000 / \mathrm{mm}^{3} . \quad X$-rays of the lungs, skull, and skeleton were normal. Biopsy of a cervical lymph node showed histiocytosis. The infant died at 12 weeks. Full necropsy was not permitted but material from the liver and spleen was obtained shortly after death. Histology of the liver showed aggregates of histiocytic-type cells with an abundant eosinophilic and granular cytoplasm in the portal spaces. In the spleen, proliferation of this type of cell involved both the red and white pulp.

Sib 2. IV-20 was born 3 years after sib 1 . He developed well until the age of 10 weeks, when he was referred for fever, pallor, and abdominal swelling, and was found to have hepatosplenomegaly and a seborrhoeiclike rash on the scalp. Hb was $7.3 \mathrm{~g} / 100 \mathrm{ml}$, with marked hypochromia. Clotting time was prolonged and platelet count was $20,000 / \mathrm{mm}^{3}$. A macular rash appeared on the limbs and trunk. He died at 12 weeks. Full necropsy was refused, but needle specimens of the liver and spleen obtained shortly after death showed histological changes identical with those observed in sib 1.

\section{The Families}

The $\mathrm{K}$ family. The parents of the 2 affected sibs are a young healthy couple. The father was 19 and the mother was 17 years old when their first child was born. They belong to a large Arab family from Northern Israel, in which consanguineous marriage has been customary for generations (Fig. 1). A family pedigree such as that recorded is not uncommon among Israeli Arabs. The paternal and maternal grandfathers of the affected are related as first cousins, hence their reproductive histories may be of interest. 16 pregnancies of IV-4 resulted in 9 infant deaths (before the age of 2 years), 5 abortions, and only 2 live children. The causes of the infant deaths are unknown and no medical records are available. Yet, even under the circumstances of high infant mortality in this particular ethnic group 30 years ago, this is far greater than expected. Though the exact relation between III-4 and III-5 (the father's paternal grandparents) is not known, they are certainly related. With this, the couple V-4 and V-19 become related through both their fathers and mothers. This of course greatly increased their chance of having inherited a recessive gene from a common ancestor.

The $\mathbf{S}$ family. This is a Druze family. The Druzes, a separate religious group, split from the Arab Moslems about one thousand years ago. They are a small population and usually marry within the group, very often within the same village. The parents of the affected children III-3 and III-9 (Fig. 2) are first-cousins once removed. This couple could not provide detailed information about previous generations, hence we know little about consanguinity among their ancestors. In their own generation, of which they knew more, the high rate of consanguinity is evident in the pedigree. Several cases of infant death are reported in generations III and IV, but there is no evidence to suggest any relation to the disease in the affected family. No information could be obtained about 
abortions or stillbirths in other couples. In addition to the 2 affected children, the parents stated in retrospect that their firstborn, a girl, died at the age of 18 months 'of the same disease'. She was never in hospital and died at home after having been sick for 10 days. Their description of her symptoms included a swollen abdomen, nose bleeding, and a rash over her body, so that this was probably another death from LettererSiwe diseae.

\section{Comment}

Familial occurrence of Letterer-Siwe disease is well known in the literature. At least 20 families, with 2 or more affected sibs, have been reported, including 8 pairs of twins (Bass, Sapin, and Hodes, 1953; Batson et al., 1955; Bierman et al., 1952; Bierman, 1966; Caldarini, 1966; Christie et al., 1954; Falk and Gellei, 1957; Glass and Miller, 1968; Harvard, Rather, and Faber, 1950; Juberg, Kloepfer, and Oberman, 1970; Lausecker, 1956; Lightwood and Tizard, 1954; Miller, 1966; Omenn, 1965; Reese and Levy, 1951; Rogers and Benson, 1962; Schoeck, Peterson, and Good, 1963). In addition, there are a number of reported families with a disease which, though not considered as Letterer-Siwe disease by the authors, must certainly belong to the histiocytosis group (Farquhar and Claireaux, 1952; Farquhar, MacGregor, and Richmond, 1958; MacMahon, Bedizel, and Ellis, 1963; Marrian and Sanerkin, 1963; Nelson et al., 1961). The cases in these families share a histological picture somewhat different from that observed in the Letterer-Siwe cases, but in common with the latter, they present with a fulminant course of histiocytosis. This high familial incidence in so rare a disease seems too large to be due to chance.

The possibility of an infective cause for this disease has been discussed (Aviolo, Lasersohn, and Lopresti, 1963; Claman et al., 1970; Dargeon, 1966) but seems unlikely, and in several familial cases, as well as in ours, there was no contact between the affected sibs.

Evidence for the genetic cause of Letterer-Siwe disease has been recently summarized by Juberg et al., who suggested an autosomal recessive mode of inheritance, with incomplete penetrance and/or genetic modifiers affecting both familial incidence and the course of the disease. In Hand-SchüllerChristian disease no familial incidence was noted in the families of 21 cases (Forssman and Rudberg, 1960). This may indicate that either HandSchüller-Christian and Letterer-Siwe disease are not really one syndrome, despite their common features, or that a genetic mechanism is operating in only the more acute variant, Letterer-Siwe disease. The striking similarity in the cases from our two families, both as to clinical course and histological findings was impressive. This similarity, reflected even in the precise age of onset, is highly suggestive of a common mechanism operating in the causation of the disease in both families. A tendency for recurrent abortions was evident in couple IV-3 and IV-4 and also in couple V-4 and $\mathrm{V}-19$ of the $\mathrm{K}$ family, who are just at the beginning of their reproductive history. Recurrent abortions have also been observed in other reported families. The possibility of this lethal gene causing an increased rate of intrauterine death should therefore be kept in mind.

With this report, the number of consanguineous families with Letterer-Siwe disease amounts to 4 out of a total of 22 affected families. Whether this represents a 'higher than expected' rate of consanguinity in the population concerned cannot be determined, but the figure is suggestively high, and provides additional support for the hypothesis of an autosomal recessive gene operating in the causation of Letterer-Siwe disease.

\section{REFERENCES}

Aviolo, L. V., Lasersohn, J. T., and Lopresti, J. M. (1963). Histiocytosis X (Schüller-Christian disease). Medicine, 42, 119.

Bass, M. H., Sapin, S. O., and Hodes, H. L. (1953). Use o cortisone and corticotrophin (ACTH) in treatment of reti culoendotheliosis in children. American fournal of Diseases of Children, 85, 393.

Batson, R., Shapiro, J., Christie, A., and Riley H. D., Jr. (1955).? Acute nonlipid disseminated reticuloendotheliosis. American Fournal of Diseases of Children, 80, 323.

Bierman, H. R. (1966). Apparent cure of Letterer-Siwe disease: seventeen-year survival of identical twins with nonlipoid reticuloendotheliosis. Fournal of the American Medical Association, 196, 368.

Bierman, H. R., Lanman, J. T., Dod, K. S., Kelly, K. H., Miller, E. R., and Shimkin, M. B. (1952). The ameliorative effect of antibiotics on nonlipoid reticuloendotheliosis (Letterer-Siwe disease) in identical twins. Fournal of Pediatrics, 40, 269.

Caldarini, G. (1966). Considerazioni su di una coppia di gemelli affetti da malattia di Letterer-Siwe. Clinica Pediatrica, 48, 315.

Christie, A., Batson, R., Shapiro, J., Riley, H. D., Jr., Laughmiller, R., and Stahlman, M. (1954). Acute disseminated (non-lipid) reticuloendotheliosis. Acta Paediatrica, 43, Suppl. 100, 65.

Claman, H. N., Suvatte, V., Githens, J. H., and Hathaway, W. E. (1970). Histiocytic reaction in dysgammaglobulinemia and congenital rubella. Pediatrics, 46, 89.

Dargeon, H. W. K. (1966). Reticuloendotheliosis in Childhood. C. C. Thomas, Springfield, Illinois.

Falk, W., and Gellei, B. (1957). The familial occurrence of LettererSiwe disease. Acta Paediatrica, 46, 471.

Farquhar, J. W., and Claireaux, A. E. (1952). Familial haemophagocytic reticulosis. Archives of Disease in Childhood, 27, 519.

Farquhar, J. W., MacGregor, A. R., and Richmond, J. (1958). Familial haemophagocytic reticulosis. British Medical fournal, 2, 1561 .

Forssman, H., and Rudberg, B. (1960). Study of consanguinity in twenty-one cases of Hand-Schüller-Christian disease. Acto Medica Scandinavica, 168, 427.

Glass, A. G., and Miller, R. W. (1968). U.S. mortality from Letterer-Siwe disease, 1960-1964. Pediatrics, 42, 364.

Harvard, E., Rather, L. J., and Faber, H. K. (1950). Nonlipoid reticuloendotheliosis (Letterer-Siwe's disease). Pediatrics, 5, 474. 
Juberg, R. C., Kloepfer, H. W., and Oberman, H. A. (1970) Genetic determination of acute disseminated histiocytosis $\mathrm{X}$ (Letterer-Siwe syndrome). Pediatrics, 45, 753.

Lausecker, H. (1956). Abt-Letterer-Siwesche Krankheit bei Zwillingen. Wiener klinische Wochenschrift, 68, 433.

Lightwood, R., and Tizard, J. P. M. (1954). Recovery from acute infantile non-lipoid reticulo-endotheliosis (?Letterer-Siwe disease). Acta Paediatrica, 43, Suppl. 100, 453.

MacMahon, H. E., Bedizel, M., and Ellis, C. A. (1963). Familial erythrophagocytic lymphohistiocytosis. Pediatrics, 32868.

Marrian, V. J., and Sanerkin, N. G. (1963). Familial histiocytic reticulosis (familial haemophagocytic reticulosis). fournal of Clinical Pathology, 16, 65.

Miller, D. R. (1966). Familial reticuloendotheliosis: concurrence of disease in five siblings. Pediatrics, 38, 986.

Nelson, P., Santamaria, A., Olson, R. L., and Nayak, N. C. (1961). Generalized lymphohistiocytic infiltration: a familial disease not previously described and different from Letterer-Siwe disease and Chédiak-Higashi syndrome. Pediatrics, 27, 931. Omenn, G. S. (1965). Familial reticuloendotheliosis with eosinophilia. New England fournal of Medicine, 273, 427.

Reese, A. J. M., and Levy, E. (1951). Familial incidence of nonlipoid reticuloendotheliosis (Letterer-Siwe disease). Archives of Disease in Childhood, 26, 578.

Rogers, D. L., and Benson, T. E. (1962). Familial Letterer-Siwe disease. Fournal of Pediatrics, 60, 550.

Schoeck, V. W., Peterson, R. D. A., and Good, R. A. (1963). Familial occurrence of Letterer-Siwe disease. Pediatrics, 32, 1055.

Correspondence to Dr. E. Freundlich, Children's Department, Government Hospital, Nahariya, Israel. 